\title{
Fundamental Basis of Production and Application of Biodegradable Polyhydroxyalkanoates
}

\author{
Tatiana G. Volova ${ }^{a, b *}$, Ekaterina I. Shishatskaya ${ }^{a, b}$, \\ Natalia O. Zhilaa ${ }^{\text {a,b }}$, Eugeny G. Kiselev ${ }^{\mathrm{a}, \mathrm{b}}$, \\ Petr V. Mironov ${ }^{c}$, Alexander D. Vasiliev ${ }^{d}$, \\ Ivan V. Peterson ${ }^{\mathrm{e}}$ and Anthony J. Sinskey ${ }^{\mathrm{b}, \mathrm{f}}$ \\ a Institute of Biophysics of $S B R A S$, \\ Akademgorodok, Krasnoyarsk 660036, Russia \\ ${ }^{b}$ Siberian Federal University, \\ 79 Svobodny, Krasnoyarsk 660041, Russia \\ c Siberian State Technology University, \\ 82 Mira av., Krasnoyarsk, Russia \\ ${ }^{d}$ Institute of Physics named after L.V.Kirenskii SB RAS, \\ Akademgorodok, Krasnoyarsk 660036, Russia \\ e Institute of Chemistry and Chemical Technology SB RAS, \\ Akademgorodok, Krasnoyarsk 660036, Russia \\ ${ }^{f}$ Massachusetts Institute of Technology, \\ Cambridge, MA 02139, USA ${ }^{1}$
}

Received 10.09.2012, received in revised form 17.07.2012, accepted 24.09.2012

Microbial polyhydroxyalkanoates (PHAs) have long been studied due to their potential for replacement of petroleum-based plastic. The study addresses the effect of different conditions of carbon nutrition on synthesis of polyhydroxyalkanoates by the bacterium Ralstonia eutropha. First and foremost, PHAs are carbon storage compounds for many organisms. There are still many aspects of the physiology of PHA accumulation and degradation that are still not understood. Measurements of key P3HBrelated enzyme activities throughout cell growth reveal correlations of acetoacetyl-CoA reductase and synthase enzyme activity maxima with P3HB biosynthesis. The investigation addressed kinetic parameters of growth and accumulation of polyhydroxyalkanoates and gas exchange parameters of the culture of the CO-resistant strain of the hydrogen bacteria Ralstonia eutropha B 5786 cultivated on synthesis gas - a product of gasification of brown coals. The results were compared with those obtained by growing the bacteria on electrolytic hydrogen and it was concluded that synthesis gas can be successfully used to produce PHAs. In experiments with wild-type strain it has been first found that

\footnotetext{
Corresponding author E-mail address: volova45@mail.ru

(C) Siberian Federal University. All rights reserved
} 
under mixotrophic growth conditions $-\mathrm{CO}_{2}+$ co-substrate (alcanoic acids) - bacteria can synthesize multi-component PHAs, consisting of short-and medium-chain-length monomers with carbon chains containing 4 to 8 atoms. It has been shown that PHA composition is determined by the type of the co-substrate. Fatty acids with odd number of carbons induce bacteria to synthesize multi-component PHAs with 3-hydroxybutyrate, 3-hydroxyvalerate, and 3-hydroxyhexanoate as major monomers and 3-hydroxyheptanoate and 3-hydroxyoctanoate as minor, occasionally occurring, ones. Fatty acids with even number of carbons induce synthesis of not only their respective monomers (3-hydroxyhexanoate and 3-hydroxyoctanoate) but also 3-hydroxyvalerate, making possible synthesis of four-component PHAs, containing 3-hydroxybutyrate and 3-hydroxyhexanoate as major components. A family of short-and medium-chain-length four-and five-component PHAs has been synthesized and their physicochemical and biomedical-properties examined.

Keywords: biopolymers, polyhydroxyalkanoates, substrates, synthesis, properties, processing, biomedical applications.

\section{Introduction}

Production of environmentally friendly materials possessing new useful properties remains one of the key tasks of the present time. The diversity of polymers with widely varying stereo-configuration and molecular weight and the feasibility of producing various composites with different materials provide the basis for obtaining a wide range of novel materials that would have new valuable properties. Recent years have seen a growing interest in studies on biopolymers (polymers of biological origin). There are two major kinds of biopolymers: polymers produced by biological systems (such as microorganisms) and chemically synthesized polymers based on biological feedstocks (amino acids, sugars, fats). In the past ten to fifteen years, biopolymer engineering has become one of the major interdisciplinary research areas. The main goal of this research is to: 1) find and study new biopolymers and 2) develop a fundamental basis for constructing biological systems capable of synthesizing polymers with target properties.

Among the biodegradable polymers that have already been developed or are being developed now for various applications, including medical ones, are aliphatic polyesters, polyamides, segmented polyester urethanes, polymers of lactic and glycolic acids (polylactides and polyglycolactides), silicon, polyethylene terephthalate, and, since recently, polymers of hydroxyalkanoic fatty acids, the so-called polyhydroxyalkanoates (PHAs) (Amass et al., 1998; Sudesh et al., 2000).

The companies that are actively developing and successfully marketing these polymers are Monsanto, Metabolix Inc., Tepha, Procter \& Gamble, Berlin Packaging Corp., Bioscience Ltd., BioVentures Alberta Inc., and Merck, which produce polymers with the tradenames Biopol $\AA$, Biopol $^{\mathrm{TM}}$, TephaFLEX ${ }^{\mathrm{TM}}$, and DegraPol/btc $\AA$. The main factors contributing to the prosperity of these companies are active marketing and promotion of products made from biodegradable polymers. Large-scale production and application of PHAs is impossible without reducing their cost. This can be achieved by using singlecarbon substrates (sugars, organic acids) and industrial wastes (from production of sugar and palm oil and hydrolysates of plant biomass). International experts estimate potential cost of PHAs at US\$ 4900 to 8300 per ton, depending on the type of feedstock, synthesis process, and 
production scale (Choi, Lee, 1999). Among the reasons why these companies have not captured the Russian market are that their products are very expensive, which is critical for the Russian consumers, whose average incomes are lower than those of consumers in North America, West Europe, and South-East Asia; and that their marketing strategies are directed towards the consumer in the regions where their products have already found recognition. The competition at the international market of biopolymers may become acuter and the prices may go down as production of biodegradable polymers is started in Germany, the Netherlands, Japan, and several other industrially developed countries.

The chemoautotrophic hydrogen-oxidizing bacterium Ralstonia eutropha (renamed now to Cupriavidus eutrophus) synthesizes variously structured high-molecular-weight PHAs in large quantities on different substrates. The ability of $R$. eutropha to synthesize PHAs autotrophically, on hydrogen and carbon dioxide, i.e. without using costly organic media, makes this bacterium a promising commercial PHA producer. Moreover, as some species of hydrogen-oxidizing bacteria are resistant to carbon monoxide, large-scale PHA production can be based on industrial hydrogen sources-hydrogen-containing products of conversion of natural gas, coal, and other natural carbon-containing compounds, including industrial wastes (wood residues, lignin, etc.). A noteworthy fact is that very few research teams are engaged in studying polyhydroxyalkanoate synthesis from hydrogen. These teams work in Japan (Tanaka et al., 1994; Sugimoto et al., 1999; Ishizaki, 2001) and in Russia, in the Institute of Biophysics SB RAS.

As PHAs are substrates of endogenous respiration, microorganisms (except Alcaligenes latus) synthesize them only under unbalanced growth conditions and high yields may be unattainable. As a rule, cells are batch cultured under growth limitation conditions, in the media deficient in nitrogen, phosphate, oxygen, etc.

Researchers of the Institute of Biophysics SB RAS studied PHA accumulation in cells of the hydrogen-oxidizing bacterium Ralstonia eutropha (Volova et al., 1992a-c, 1996a, b) and of the new species - the aerobic carboxydobacterium Seliberia carboxydohydrogena (Volova et al., 1994). Thorough investigation of polyhydroxybutyrate (PHB) synthesis by cells of $R$. eutropha B 5786 showed that in the batch culture the highest yields of the polymer can be achieved in a two-phase process: in Phase - cells are grown in the medium containing growthlimiting amounts of nitrogen and in Phase 2 - in nitrogen-free medium. In Phase - sufficient cell biomass is accumulated, with cells containing about $40-50 \%$ of the polymer. So, Phase 2 can last a much shorter time and the total culture duration is $60-70 \mathrm{~h}$ (Volova et al., 1990, 1992a). Thus, high polymer yields $(80-90 \%)$ can be obtained in a rather short-duration process $(60-70 \mathrm{~h})$, with biomass concentration amounting to $35-50 \mathrm{~kg} / \mathrm{m}^{3}$ (Volova, Voinov, 2003, 2004).

As most microorganisms (except Alcaligenes latus) accumulate PHAs most actively under the conditions of unbalanced growth caused by a deficiency of a biogenic element (nitrogen, phosphorus or oxygen), the main problem of developing a technology is to find the conditions that would provide both high polymer yields and sufficiently high yields of bacterial biomass. This is usually attained by using two-stage batch culture: at the first stage the conditions are optimal for biomass growth and at the second under non-optimal conditions, such as lack of nitrogen, polymer accumulation occurs. Earlier we developed a two-stage cultivation procedure, according to which bacteria are cultivated in a nitrogen-deficient medium in the first stage and in nitrogen-free medium in the second stage. As a result, the second stage of fermentation becomes 
shorter and polymer yield increases (up to more than $70 \%$ ) (Volova, Kalacheva, 2005).

\section{Hydrogen bacteria and synthesis of PHA}

The accumulation of biomass and polymer in the culture of the bacteria R.eutropha on the gas substrate (synthesis gas) containing various amounts of carbon monoxide versus control $\left(\mathrm{CO}_{2}+\mathrm{O}_{2}+\mathrm{H}_{2}\right)$ has two phases. It is evident that in the first stage $(30 \mathrm{~h})$, when the culture grew under nitrogen deficiency (nitrogen supply was $50 \%$ of culture's physiological requirement) and the specific growth rate of bacteria gradually decreased from 0.17 to $0.09 \mathrm{~h}^{-1}$, the concentration of cells in the culture could reach $10-15 \mathrm{~kg} / \mathrm{m}^{3}$. By the end of this stage, the polymer content in the biomass was about $45-50 \%$. In the second stage, when the medium was nitrogen free, the polymer concentration in the cells grew to $75 \pm 5 \%$. The yield coefficient of the culture in the first stage averaged $1.5 \mathrm{~kg}$ dry biomass $/ \mathrm{kg}$ for $\mathrm{H}_{2}, 0.34$ for $\mathrm{O}_{2}$, and 0.48 for $\mathrm{CO}_{2}$; in the second stage $0.9,0.2$, and 0.4 , respectively.

Autotrophically growing hydrogen bacteria use hydrogen, which is a poorly soluble gas, as an energy substrate, and, thus, their growth kinetics are mainly determined by the transport of the gaseous substrate to the liquid phase. Therefore, hydrogen bacteria, especially those grown in batch culture, having passed through the exponential phase, enter a short linear growth phase, which, as cell concentration in the suspension increases and gas-dynamic properties of the medium grow worse, is replaced by the slower-growth phase, quickly followed by the establishment of a stationary state. In the middle of the linear growth phase, intracellular protein concentration stabilizes, and cells begin to synthesize storage P3HB. Analysis of the intracellular P3HB content in the stored culture, maintained on mineral agar slant at $5^{\circ} \mathrm{C}$, showed that polymer reserve in the cells did not exceed 6-9 \% of dry weight. Cells with polymer content below $10 \%$ were inoculated onto Schlegel mineral salt medium. In 4-10 h after the inoculation and the onset of cell growth, intracellular $\mathrm{P} 3 \mathrm{HB}$ content dropped to trace amounts. In the first phase of bacterial cell culture (4-16 h), gross and specific rates of $\mathrm{P} 3 \mathrm{HB}$ synthesis were low: $0.013 \mathrm{~g} / \mathrm{h}$ and $0.08 \mathrm{~h}^{-1}$, respectively. In the following 30-40 h, both cell concentration in the culture and the intracellular P3HB content increased. P3HB content in the cells cultured for 20-25 $\mathrm{h}$ amounted to about $30 \%$. By the middle of the linear growth phase, intracellular polymer content reached about $50 \%$, and gross and specific rates of P3HB synthesis were $0.31 \mathrm{~g} / \mathrm{h}$ and $0.146 \mathrm{~h}^{-1}$, respectively. The highest polymer content was recorded in the stationary phase, $86.0 \%$, while intracellular protein content was as low as $8.1 \%$. P3HB synthesis rate dropped to its initial value. Then, as the culture left the stationary phase and entered the negative growth phase (or the death phase), the intracellular polymer reserve was reduced and the value of biomass concentration $(\mathrm{g} / \mathrm{L})$ gradually decreased. By the end of the experiment intracellular $\mathrm{P} 3 \mathrm{HB}$ concentration had dropped nearly 4 times, to $19.3 \%$, while protein concentration had increased to $49.8 \%$. The behavior of bacterial cells grown heterotrophically, on fructose, was similar.

\section{PHA biosynthesis from syngas}

One of the main principles of industrial biotechnology - availability of feedstock-implies both the stable presence of economic material and the feasibility of promptly replacing one source with another, without significantly changing the technological process or impairing the quality of the resultant product. Hydrogen-oxidizing bacteria are usually grown on gases (carbon dioxide, oxygen, and hydrogen). Hydrogen is the scarcest component of the gas substrate and it is essential to find the ways to lower its cost 
in order to develop hydrogen biosynthesis for practical purposes. Polyhydroxyalkanoates can be produced from various substrates, among them individual compounds (carbon dioxide and hydrogen, sugars, alcohols, organic acids); waste products of the alcohol, sugar, and hydrolysis industries and olive and palm oil production; etc. (Tanaka et al., 1994; Cromwick et al., 1996; Lee, 1998; Sugimoto et al., 1999). There are also unconventional substrates, including toxic ones. PHAs can be synthesized from the poorly soluble and toxic octane and octanoate, sodium benzoate, phenol, and methacrylic acid (Lee et al., 1997; Hazenberg, Witholt, 1997; Durner et al., 2000).

Recently, more attention has been drawn to coals and coal products as substrates for biotechnologicalproduction(Fakoussa,Hofrichter, 1999). Large reserves of coals and their relatively low cost make them very promising materials for the future large-scale industrial production of microbial bioplastics. It has recently been shown that the bacterium Pseudomonas oleovorans can synthesise PHA terpolymers poly(3hydroxyhexanoate-co-3-hydroxydecanoate-co-3hydroxydodecanoate) and Rhodobacter rubberpoly(3-hydroxybutyrate-co-3-hydroxyvalerate) copolymers on the media containing coal liquefaction products (mixtures of humic acids (Füchtenbuch, Steinbüchel, 1999). Among hydrogen bacteria, there are unique organisms resistant to $\mathrm{CO}$. This is the strain Alcaligenes eutrophus Z1 from Academician G.A. Zavarzin's collection at the Institute of Microbiology RAS (Savelieva, 1979; Volova et al., 1985) and its fastgrowing strain, A.eutrophus B5786 (Stasishina, Volova, 1996). These organisms can be grown on industrial sources of hydrogen that contain carbon monoxide (converted gas and coal and lignin gasification products) (Volova, Voinov, 2003, 2004; Volova et al., 2002).

Carbon monoxide is a respiratory poison. In microorganisms $\mathrm{CO}$ inactivates iron-containing enzymes of the electron transport chain. The type and the strength of the damaging impact of $\mathrm{CO}$ on hydrogen bacteria (A. eutrophus Z1) and carboxydobacteria ( $S$. carboxydohydrogena Z1062) have been studied before (Volova et al., 1985, 1993). In cultures of the mentioned organisms grown on complete nutrient medium under turbidostat conditions an increase in $\mathrm{CO}$ concentration caused a dramatic decrease in the specific growth rate of the cells, increases in the activity of hydrogenase (the key enzyme of hydrogen metabolism) and cytochrome concentration, and enlargement of the cell membrane system.

Bacterial cells of this species can accumulate large amounts of PHA under unbalanced growth conditions, with protein synthesis reactions limited and carbon and energy present in abundance. The largest PHA concentrations ( $80 \%$ of dry biomass and even more) are accumulated under nitrogen deficiency. However, nitrogen limitation of cell growth, like any other unfavorable factor, reduces the efficiency of hydrogen utilization and increases the overall consumption of the gas mixture in the culture ("Proizvodstvo...", 1980). The consequencesofthetwo-factorinfluence(nitrogen deficiency combined with $\mathrm{CO}$ inhibition) for $A$. eutrophus or any other microorganism had not been studied before. So, the authors analyzed not only polymer yields and activities of the key enzymes but also the efficiency of gaseous substrate utilization, hydrogenase activity, and the chemical composition of cells. Based on the previously derived kinetic dependence of specific growth rates of A. eutrophus $\mathrm{B} 5786$ from CO concentration (Volova et al., 2001, 2002), bacterial cells were grown on model gas mixtures containing 5-25 \% $\mathrm{CO}, \mathrm{v} / \mathrm{v}$. Whatever $\mathrm{CO}$ concentration was contained in the gas mixture, cells of A. eutrophus B5786 accumulated up to $70-75 \%$ PHA, with the overall 
biomass yield amounting to levels similar to the control ones (Volova et al., 2001).

To reveal possible reasons why $\mathrm{CO}$ did not exert any significant effect on the ability of bacteria to synthesize PHA, a study was performed in which physiological-biochemical parameters of the cultures accumulating PHA in the medium with and without $\mathrm{CO}$ were compared with the earlier results obtained in experiments investigating the effect of one factor - either nitrogen deficiency or $\mathrm{CO}$ - on bacterial cells. Hydrogenase activity in the cells accumulating PHA in the presence of $\mathrm{CO}$ was as high as that of the cells grown under optimum conditions in continuous culture. Moreover, when $\mathrm{CO}$ concentration in the mixture increased, the hydrogenase activity became significantly, 1.31.5 times, higher.

A similar but even more pronounced reaction was observed in bacterial cells inhibited by one factor only - carbon monoxide at a concentration of more than $20 \%$, i.e., hydrogenase activity almost doubled while the total gas consumption increased and the yield coefficient from hydrogen dropped. However, under the maximum PHA accumulation by the cells whose nitrogen requirements were $50 \%$ fulfilled, no significant changes were registered in hydrogenase activity; under chemostat conditions, in nitrogen limited culture, activity of the enzyme halved, although gas consumption increased.

The fact that CO produces no adverse effect on PHA synthesis system in CO-resistant cell cultures of hydrogen bacteria offers opportunities for producing these polymers from gaseous products derived from coal via thermal treatment, such as coal gasification products. However, syngas used for this purpose must conform to certain requirements and one of them is that its $\mathrm{H}_{2} / \mathrm{CO}$ ratio must amount to at least 3 . The syngas must be free of carcinogenic tarry substances and any other biologically hazardous compounds.
Moreover, the process of brown coal gasification must be economically acceptable.

The subsequent study addressed kinetic parameters of $R$. eutropha B5786 culture accumulating PHA on syngas and efficiency of substrate utilization under different gas supply conditions (Volova, Voinov, 2003, 2004); CO concentrations up to $20 \% \mathrm{v} / \mathrm{v}$ did not affect either the dynamics of accumulation or the output of the polymer. PHA concentration at the end of the fermentation cycle reached $70-75 \%$. The end concentration of the gross biomass in the culture grown on syngas was similar to the control value. The stoichiometry of gas component consumption, which characterizes the quantitative relationship between the initial substrate and the end product, was not significantly different from the parameters of the culture grown on $\mathrm{CO}$-free gas substrate. These findings made it possible, for the first time in practical biotechnology, to synthesize high yields of polyhydroxyalkanoates from products derived from brown coals via modified gasification procedure. PHA biotechnology on syngas has been protected by RF Patent No. 2207375.

\section{Synthesis \\ of PHA heteropolymers}

Synthesis of multi-component PHAs is a very complicated biotechnological task. To cope with it, one has to take into account a number of factors. First, fast-growing bacterial cultures, except Alcaligenes latus, cannot produce high PHA yields, and special growth conditions must be created to attain high polymer yields along with high total biomass production. Second, monomers differing in the number of carbon atoms cannot be incorporated into the polymer at the same rate, thus, in microorganism culture, fractions of monomers in PHA are unstable. Third, hydrocarbon acids, which are used as cosubstrates, are toxic to most microbial cultures, so 
it is essential to determine maximal permissible concentrations of every acid for every PHA producer. Thus, production of multi-component PHAs in dense cultures, with high intracellular content of PHA (over 50-60 \%) containing longchain monomers as the major ones, is rather problematic.

Researchers of Institute of Biophysics SB RAS compared the accumulation and structure of the polymers synthesized by different strains of Ralstonia eutropha (previously known as Alcaligenes eutrophus): Al. eutrophus Z1 (kindly provided by Academician G.A. Zavarzin), its fastgrowing variant $R$. eutropha B5786 (Stasishina, Volova, 1996), and the recently engineered glucose-assimilating mutants $R$. eutropha $\mathrm{B} 8562$ and Cupriavidus eutrophus B10646. All strains were found to synthesize high yields of PHAs under autotrophic and heterotrophic growth conditions (75-80\% and $90 \%$, respectively). The polymers, however, had different chemical structures. The PHA synthesized by $\mathrm{Z1}$ is a homopolymer of 3-hydroxybutyric acid; B5786 synthesizes a copolymer containing 3-hydroxybutyric acid ( $>99$ mol. \%) and minor amounts of 3-hydroxyvaleric acid; the mutant glucose-assimilating strain, B8562, grown on the single carbon substrate, synthesizes a terpolymer with 3-hydroxybutyric acid as a major component and 3-hydroxyvaleric and 3-hydroxyhexanoic acids amounting to 0.2-0.6 mol. \% and 1-4 mol. \%, respectively. Thus, these microorganisms must synthesize polyhydroxyalkanoates via different pathways and strains B5786 and B8562 must have alternative pathways of synthesis of amino acids, which supply monomers for PHAs, and their PHA-synthase (the enzyme catalyzing polymerization of hydroxy-derived fatty acids) must have broader substrate specificity.

To determine the conditions of controlled synthesis of $\mathrm{P}(3 \mathrm{HB}-\mathrm{co}-3 \mathrm{HV})$, accumulation of the copolymer was studied in the culture with complex growth substrate. Valerate added to the culture of R.eutropha B5786 cells was utilized by the cells and 3-hydroxyvalerate monomers were incorporated in the polymer. As valerate concentrations higher than $2 \mathrm{~g} / \mathrm{L}$ are toxic to $R$. eutropha B5786 cells, we made an attempt to increase the percentage of incorporated 3-hydroxyvalerate by adding the co-substrate in several small portions. By varying both the number of valerate supplementations $(1,2,3$, and more) and the subsequent culture time, we determined the conditions for $\mathrm{P}(3 \mathrm{HB}-\mathrm{co}-3 \mathrm{HV})$ synthesis with $3 \mathrm{HB}: 3 \mathrm{HV}$ monomer ratios varying within a wide range, from 9:1 to 1:9 (mol. \%). Thus, a high copolymer yield (>70-75\%) was achieved, and the resulting PHAs contained different percentages of the monomers (Volova, Kalacheva, 2005; Volova et al., 1996a).

The subsequent studies were aimed at finding out whether the bacteria could synthesize PHA terpolymers, containing not only 3-hydroxybutyrate and 3-hydroxyvalerate but also longer-chain-length monomers. It is noteworthy that not long ago PHA synthases were considered to be highly substrate specific (Steinbüchel, Valentin, 1995). Thus, wild strains were assumed to be unable to synthesize polymers containing both short-chain $\left(\mathrm{C}_{3}-\mathrm{C}_{5}\right)$ and medium-chain $\left(\mathrm{C}_{6}\right.$ $\mathrm{C}_{12}$ ) monomers.

Experiments were performed to compare the formation, accumulation, and chemical structure of PHAs consisting of short- and mediumchain monomers by of R. eutropha B5786 under different conditions of carbon nutrition (Volova et al., 2008).

Strain B5786 was isolated in Russia and it is a fast-growing variant of $R$. eutropha $\mathrm{Z} 1$ the strain isolated by the team of researchers headed by Academician G.A. Zavarzin. Cells were batch-cultured aseptically, on Schlegel mineral salt medium, in 1-L $50 \%$ filled flasks on a temperature-controlled shaker. Autotrophic 
cultures were grown with $\mathrm{CO}_{2}$ and $\mathrm{H}_{2}$ as carbon and energy source and heterotrophic ones - with fructose. The proportions of $\mathrm{CO}_{2}, \mathrm{O}_{2}$ and $\mathrm{H}_{2}$ in the gas mixture were 1:2:6 (v/v). In heterotrophic cultures, fructose concentration was maintained at the level of $10 \mathrm{~g} / \mathrm{L}$. To achieve the maximum synthesis and accumulation of PHA, cells were cultured in two phases - in nitrogen-limited medium in the first and nitrogen-free one in the second, at $\mathrm{pH} 7.0$ and temperature $30^{\circ} \mathrm{C}$. To stimulate synthesis of heteropolymers, the culture medium was supplemented with salts of fatty acids (valerate, hexanoate, heptanoate, and octanoate) (Sigma) of 0.5-2.0 g/L. The chemical structure of the recovered and twice precipitated polymer was examined using a gas chromatograph/mass spectrometer. The monomers were identified based on their retention time and mass spectra.

Grown autotrophically, under growth limitation by nitrogen deficiency, on single carbon substrate $\left(\mathrm{CO}_{2}\right)$, the strain yielded similar amounts of the polymer. The 48-h fermentation of strain B5786 resulted in biomass yield $6.1 \mathrm{~g} / \mathrm{L}$ and polymer concentration $61.4 \%$. The major component of the polymers synthesized by strain was 3-hydroxybutyrate (96.6 mol. \%) and minor components were 3-hydroxyvalerate (2.8 mol. \%) and 3-hydroxyhexanoate (3HHx) (0.6 mol. \%).

To achieve synthesis of PHA heteropolymers, number of factors should be taken into account. First, high PHA yields cannot be attained in fast-growing cultures, except Alcaligenes latus. Special conditions have to be created to ensure both high polymer yields and high biomass harvests. Second, monomers with different carbon chain lengths are incorporated into the polymer at different rates and, thus, their proportions during culturing are not stable. Third, fatty alkanoic acids used as co-substrates are toxic to most microbial cultures, so, preliminary determination of the maximum concentration limit for each acid and each producer is mandatory. Thus, high intracellular concentrations (more than 50-60\%) of PHA heteropolymers containing medium- and long-chain monomers as major components are hardly achieved in dense cultures.

The addition of valerate to the 12-h culture (with biomass concentration $2.7 \mathrm{~g} / \mathrm{L}$ and polymer content $22 \%$ ) increased biomass yields to 4.1$4.8 \mathrm{~g} / \mathrm{L}$ and polymer yields to $48.9-63.8 \%$. By the end of the experiment intracellular polymer content had exceeded $90 \%$. Strain synthesized tetra- and penta-polymers. The major monomers were $3 \mathrm{HB}$ and $3 \mathrm{HV}$ and the minor ones 3HHx, 3-hydroxyheptanoate (3HHp), and 3-hydroxyoctanoate (3HO). However, 3HHx and $3 \mathrm{HO}$ were detected just in some polymers. Monomer proportions in the PHA varied depending on how long the cells were cultured after the addition of the co-substrate. The composition of the recovered and purified PHA from 36-h and 48-h cultures was similar to that of the biomass subjected to direct methanolysis, indicating the absence of free monomers in the cells. By varying the portions of valerate added to the culture and the duration of the subsequent culture, we obtained PHAs containing 68.4 mol. $\%$ of $3 \mathrm{HV}$ in cells.

Cells grown on $\mathrm{CO}_{2}$ and heptanoic acid synthesized polymers with $3 \mathrm{HV}$ and $3 \mathrm{HB}$ as major components. 3HHp inclusions were insignificant $(<2$ mol. \%) and $3 \mathrm{HHx}$ and $3 \mathrm{HO}$ were registered irregularly and their amounts were very low. The qualitative composition of the recovered polymers was similar to that of biomass subjected to methanolysis, varying depending on the culture duration. The polymer yield was similar to that in the experiment with valerate (more than $90 \%$ ).

The cells of the studied strains grown on $\mathrm{CO}_{2}$ and salts of even-chain fatty acids synthesized PHA heteropolymers of different compositions. With hexanoate added to the culture, both strains synthesized the PHA containing $3 \mathrm{HV}$ and medium-chain $3 \mathrm{HH}_{\mathrm{X}}$ as the major components. 
The process of polymer accumulation was typical of the autotrophic culture and the highest percentage of $3 \mathrm{HHx}$ (13 mol. \%) was registered in the polymer after $24 \mathrm{~h}$ of the culture supplemented with the fatty acid. By that time, intracellular polymer content had exceeded $50 \%$. In addition to $3 \mathrm{HHx}$, the polymers also contained $3 \mathrm{HO}(0.6-1.5$ mol. \%) and $3 \mathrm{HV}(1.0-2.7 \mathrm{~mol}$. \%). By the end of the experiment intracellular polymer concentration had increased to $70 \%$, while the $3 \mathrm{HHx}$ fraction dropped to $11 \mathrm{~mol} . \%$, and the $3 \mathrm{HV}$ fraction to $1.4 \mathrm{~mol} . \%$; the percentage of $3 \mathrm{HO}$ remained unchanged, $1.5 \mathrm{~mol}$. \%. The composition of the recovered and purified polymers was similar in both strains and did not differ from that of the biomass subjected to methanolysis. The increase in $3 \mathrm{HO}$ percentage may suggest that monomer precursors can be formed in the cell not only due to $\beta$-oxidation of fatty acids but also in the course of elongation of an acyl chain.

The addition of just $0.5 \mathrm{~g} / \mathrm{L}$ of octanoate, which is toxic to bacteria, inhibited cell growth and polymer synthesis. As octanoate level in the culture medium of B5786 was decreased, biomass growth and polymer synthesis were re-established. At the end of the experiment intracellular PHA concentration amounted to 70-77 \%, and biomass yield - to 7.8-8.7 g/L. In this experiment the qualitative composition of the polymers recovered after $36 \mathrm{~h}$ of the culture supplemented with octanoic acid was significantly different from that of biomass samples: the recovered polymers contained elevated amounts of $3 \mathrm{HV}$ (24.8 mol. \%), some 3HHp (0.2 mol. \%), and smaller amounts of $3 \mathrm{HO}(2.1 \mathrm{~mol} . \%$ in the biomass polymer and $0.7 \mathrm{~mol} . \%$ in the recovered polymer). By the end of the experiment these differences had become insignificant: $3 \mathrm{HB}-91.7$; $3 \mathrm{HV}-4.59$; $3 \mathrm{HHx}-2.55$; $3 \mathrm{HO}-1.17 \mathrm{~mol}$. \%.

PHA types that, in addition to $3 \mathrm{HB}$, contained $3 \mathrm{HHx}$ as a major component ( 2 to 18 mol. \%) were first synthesized in our experiments.
Analysis of X-ray spectra revealed a clear relationship between the degree of crystallinity $\left(\mathrm{C}_{\mathrm{x}}\right)$ of the PHA and the 3HHx percentage. As the 3HHx percentage increased, the PHA degree of crystallinity smoothly decreased. Hence, $3 \mathrm{HHx}$ affects this parameter in the same way as $3 \mathrm{HV}$, making the material less crystalline and easier to process. The temperature characteristics of the PHA also changed as the $3 \mathrm{HHx}$ percent increased. Within the studied range of $3 \mathrm{HHx}$ increase (from a few to 18 mol. \%) melting temperature $\left(\mathrm{T}_{\mathrm{m}}\right)$ and thermal decomposition temperature $\left(T_{d}\right)$ decreased, but the difference between $T_{m}$ and $T_{d}$ was not great.

These results, first of all, suggest similar trends in the PHA synthesis by cells of R. eutropha. The data suggest that even under autotrophic conditions, without acid additions, strain synthesize a terpolymer with minor inclusions of $3 \mathrm{HV}$ and $3 \mathrm{HHx}$. Grown mixotrophically $\left(\mathrm{CO}_{2}\right.$ + a fatty acid), the strain synthesize tetra- and penta-polymers with $3 \mathrm{HB}, 3 \mathrm{HV}$, or $3 \mathrm{HHx}$ as major monomers. The high level of $3 \mathrm{HV}$ in the polymer that we registered in experiments with odd-chain fatty acids was an expected result, in good agreement with the literature data. However, there are no literature data on high levels of $3 \mathrm{HHx}$ in the polymers synthesized by Ralstonia strains, although this PHA type attracts much attention.

Thus, synthesis of PHA heteropolymers consisting of short- $\left(\mathrm{C}_{4}-\mathrm{C}_{5}\right)$ and medium-chain $\left(\mathrm{C}_{6}-\mathrm{C}_{8}\right)$ monomers by natural (not recombinant) PHA producing strains of the genus Ralstonia, which are characterized by broad substrate specificity (as we proved earlier), can be achieved using one of two approaches based on:

1) parameterically controlled cultures of bacterial cells, based on the author's knowledge that a) the rates of synthesis of the total polymer pool, 3-hydroxybutyrate in particular, are different from the rates of synthesis of other components, which have longer carbon chains; b) proportions 

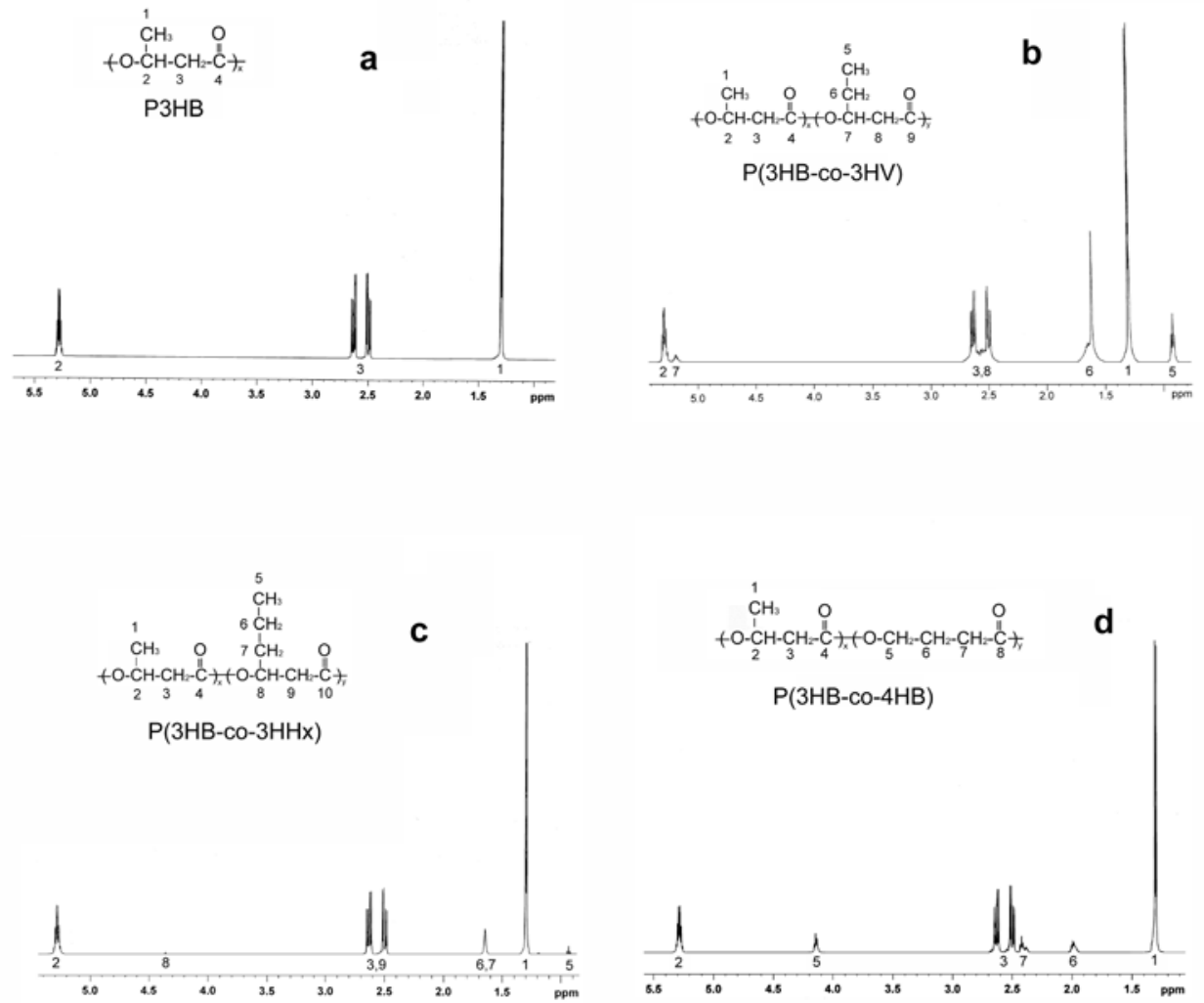

Fig.1. ${ }^{1} \mathrm{H}-\mathrm{NMR}$ spectra of different types of PHAs: $\mathrm{a}-\mathrm{P}(3 \mathrm{HB})$; $\mathrm{b}-\mathrm{P}(3 \mathrm{HB}-\mathrm{co}-3 \mathrm{HV}), 3 \mathrm{HV}-14$ mol.\%; $\mathrm{c}-\mathrm{P}(3 \mathrm{HB}-$ co-3HHx), 3HHx - 3 mol.\%; d - P(3HB-co-4HB), 4HB - 16 mol.\%

of monomers in the PHA are not stable and the highest levels of $3 \mathrm{HB}$ and $3 \mathrm{HHx}$ are registered in a certain time after the culture is supplemented with a co-substrate; c) co-substrates are toxic to bacterial cells and their concentrations must not exceed the limits established for every strain individually;

2) the feasibility of metabolically regulating biosynthesis of intracellular macromolecules by inhibiting the $\beta$-oxidation pathway and preventing the carbon chain of medium-chain monomers from being shortened in $\beta$-oxidation reactions, thus allowing this type of monomers, 3HHxe in particular, to accumulate in the cell pool and be subsequently incorporated in the PHA.

Based on this, we created such conditions of biosynthesis that allowed us to synthesize a series of PHA heteropolymers, some of them of the new chemical structure (Fig.1). We recovered and purified the synthesized heteropolymers using optimized techniques, preparing high-purification specimens, and studied their physicochemical properties (Fig.2). As the percentage of 3HHx increases, this affects PHA properties like $3 \mathrm{HV}$ does (as we determined earlier): the PHA remains thermoplastic (with a slight decrease in the melting point and the temperature for the onset of decomposition) and its crystallinity degree falls below $50 \%$; with $3 \mathrm{HHx}$ amounting to $50 \%$ of the $\mathrm{PHA}$, it is even lower $-36 \%$.

By varying the conditions of carbon nutrition, including the main carbon substrate and its concentration, and the mode of feeding the supplementary substrate ( $\gamma$-butyrolactone) into the culture, we managed to maximize the yields of the polymer and total biomass of Cupriavidus 

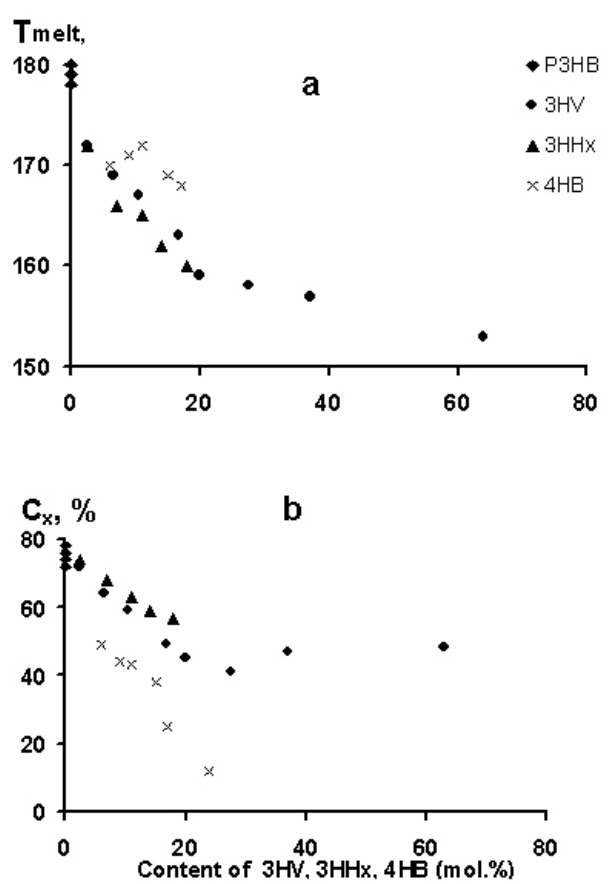

Fig. 2. Relationship of melting temperature (a) and degree of crystallinity (b) of PHA copolymers to the ratio between the $3 \mathrm{HB}$ monomer and a second monomer: $3 \mathrm{HV}, 3 \mathrm{HHx}, 4 \mathrm{HB}$

eutrophus B10646. The maximum tolerable concentration of $\gamma$-butyrolactone for this strain is 15-20 g/L. In the culture of C. eutrophus B10646 grown autotrophically and heterotrophically, the content of 4HB in the copolymer was higher as compared to the culture of $R$. eutropha (up to 15 mol. \%); biomass production and the total polymer yield were also higher, amounting to 6-7 g/L and 81-85\%, respectively.

There are reports in the literature describing the addition of acetate, propionic acid and amino acids to the media containing $\gamma$-butyrolactone in order to increase $4 \mathrm{HB}$ content in the $\mathrm{P}(3 \mathrm{HB}-$ co-4HB) copolymer. The favourable effect of these additional carbon substrates on copolymer synthesis and the $3 \mathrm{HB} / 4 \mathrm{HB}$ ratio can be attributed to the fact that utilization of these compounds is accompanied by an increase in the intercellular storage of acetyl-CoA, thus inhibiting the reaction of ketolysis of 4-hydroxybutyryl-CoA to 2 molecules of acetyl-CoA and leading to the increase in $4 \mathrm{HB}$ content in the storage and its incorporation into the copolymer (Lee et al., 2000). In some studies 4HB fraction was increased to $60-80 \mathrm{~mol}$. \%, although the total polymer yield was low $(<45 \%$ of dry weight) (Kimura et al., 1999; Lee et al., 2000; Kimura et al., 2008).

Cultivation of C. eutrophus B10646 in the medium containing propionic acid, as the main substrate $(2 \mathrm{~g} / \mathrm{L})$, and $\gamma$-butyrolactone resulted in the synthesis of three-component polymer containing $8.1 \mathrm{~mol} . \%$ 4HB and $35.2 \mathrm{~mol} . \%$ 3HV, in addition to $3 \mathrm{HB}$. Better results were obtained in the culture of C. eutrophus B10646 grown on butyric acid supplemented with $\gamma$-butyrolactone as the carbon source. Biomass yield and polymer content varied depending on $\gamma$-butyrolactone concentration. The yields were $6.2-8.2 \mathrm{~g} / \mathrm{L}$ and $72-89.7 \%$ of dry biomass, respectively; $4 \mathrm{HB}$ content varied in the range $8.7-24.3 \mathrm{~mol}$. \%. Cupriavidus eutrophus B10646, exhibiting 
enhanced tolerance to $\gamma$-butyrolactone, was cultivated on $\gamma$-butyrolactone as a single carbon substrate, which resulted in higher 4HB content in the copolymer and shorter cultivation time.

It was shown that the incorporation of 4HB influences considerably (to a greater extent than the incorporation of $3 \mathrm{HV}$ or $3 \mathrm{HHx}$ ) the ratio of crystalline to amorphous phase in the copolymer, significantly reducing its crystallinity. Crystallinity degrees of the $\mathrm{P}(3 \mathrm{HB}-$ co-4HB) copolymers containing 8.7 to $16 \mathrm{~mol}$. \% 4HB amounted to $43-44 \%$, and this was in good agreement with the data reported by other authors (Doi et al., 1990; Nakamura et al., 1992; Tsuge, 2002). For instance, Mitomo et al. showed that crystallinity degrees of the copolymers with $4 \mathrm{HB}$ content of 19, 38 and 65 mol. \% amounted to 40 , 18 and $27 \%$, respectively. The authors assumed that the crystallinity degree of the copolymer is the lowest when the 4HB fraction amounts to 40$50 \mathrm{~mol}$ \% (Mitomo et al., 2001). Other authors, however, reported the lowest crystallinity degree, $17-18 \%$, for polymers with $4 \mathrm{HB}$ content of $78-82$ mol. \% (Saito, Doi, 1994).

The melting temperature of the produced $\mathrm{P}(3 \mathrm{HB}-$ co-4HB) specimens were lower (168.9$\left.172.5^{\circ} \mathrm{C}\right)$ than that of poly(3-hydroxybutyrate) $\left(180^{\circ} \mathrm{C}\right)$. However, no relationship was found between $4 \mathrm{HB}$ content in the range from 8.7 mol. \% to $17 \mathrm{~mol}$. \% and the melting point. The decomposition temperature of copolymer specimens varied from $264^{\circ} \mathrm{C}$ to $286^{\circ} \mathrm{C}$ and did not depend on the content of $4 \mathrm{HB}$. Literature data on the $\mathrm{P}(3 \mathrm{HB}-\mathrm{co}-4 \mathrm{HB})$ melting temperature are also contradictory. Some authors reported the melting points of the samples containing $7 \mathrm{~mol} . \%$, $11 \mathrm{~mol} . \%$ and $15 \mathrm{~mol} . \%$ 4HB as 173, 169 and $160.8^{\circ} \mathrm{C}$, respectively (Kunioka et al., 1989; Doi et al., 1990; Rao et al., 2010), while in other studies the melting points of the specimens containing similar amounts of $4 \mathrm{HB}$ were considerably lower: $114^{\circ} \mathrm{C}$ and $131.5^{\circ} \mathrm{C}$ (Xie, Chen, 2008).

\section{Polymer production process}

\section{in the pilot production facility}

The first Russian pilot facility for production of polyhydroxyalkanoates was constructed and launched in January 2005 at the Krasnoyarsk Research Center of the Siberian Branch of the Russian Academy of Sciences. That was the outcome of cooperation between researchers of the Institute of Biophysics SB RAS and specialists of the Biotechnology Department at the "Biokhimmash" company (Moscow) within the framework of the International Science \& Technology Center project (Volova et al., 2006a).

The Pilot Production Facility, based on the previously developed technology, can produce sufficient quantities of polymers to satisfy the requirements of all Russian research institutes and to perfect the technologies of manufacturing special polymer items. The PPF can serve as a tool to work on PHA production technology: to use new feedstocks, to reduce the cost of the polymer, to broaden the range of the synthesized PHAs, and to obtain the data for the further scaleup of the process to the commercial level.

The pilot lots of variously structured polymers were used to develop the techniques and procedures of processing the polymers into various items. PHAs in different phase states proved to be usable for the production of films, 3D membranes, sutures, microparticles, and composites. PHAs and PHA-based items were examined in biomedical studies, exhibiting good functional properties, and proved to be biomedical grade materials (Volova et al., 2003a, 2006b).

\section{Biomedical studies \\ and use of PHA}

Recent advances in transplant surgery and introduction of new materials in medicine have made biological safety of medical items, primarily implants, a critical issue. The materials for fabricating temporary implants (sutures, artificial 
pericardia, stents, etc.) must be biocompatible, and also be prone to biodegrade, forming products that are nontoxic to the organism. To find materials possessing the latter property is a great challenge. Biodegradable materials and implants made from them are designed to repair tissues or organs and to be controllably degraded once they have been replaced by native biological structures.

Biomedical studies of PHAs were performed in conformity with the international standard ISO 10993 Biological Evaluation of Medical Devices. The studies included sanitary-chemical tests, in vitro systems, short- and long-term experiments on laboratory animals. Polymers and polymeric items such as film scaffolds and suture fibers were evaluated in conventional sanitary-chemical, toxicological, and biomedical tests. The results of the tests proved that two PHA types synthesized and purified at the Institute of Biophysics SB RAS, $\mathrm{P} 3 \mathrm{HB}$ and $\mathrm{P}(3 \mathrm{HB}-c o-3 \mathrm{HV})$, are highly biocompatible at the level of the cell, tissue, and microorganism and can be used in contact with blood (Shishatskaya et al., 2001, 2002a,b, 2004, 2005, 2006, 2008, 2011; Volova et al., 2003a, b, c, 2006b; Sevastianov et al., 2003).

A very important issue is a mechanism and kinetics of degradation of resorbable materials in biological media. Investigations of PHA degradation were conducted in biological media in vitro (in stabilized blood and serum) and in vivo, with implants (films, sutures, and microparticles) immediately contacting with animal tissues and with implants enclosed in diffusion chambers, which did not allow fibrous capsules to be formed and provided conditions for investigating biocompatibility and biostability of the material in terms of true cellular reaction. PHAs were found to be degraded in biological media at low rates (for months and years) via humoral and cellular pathways, involving macrophages and foreign body giant cells with a high activity of acid phosphatase. It was also found that PHA biodegradation rate depends on the chemical structure of the polymer, the form of the item and implantation site (Shishatskaya et al., 2002a, b, 2005).

An important property of PHAs is their processibility into special items from different phase states, using conventional techniques, without adding processing aids or plasticizers (Amass et al., 1998). Having investigated the dissolution and melting behavior of PHAs and physicochemical properties of polymer solutions, gels, and melts, we prepared a series of various 2D and 3D matrices for cell cultures: flexible films and porous membranes, monofilament fibers of diameter 0.15-0.40 mm, ultrathin fibers of diameter 1-5 $\mu \mathrm{m}$, microparticles, sponges, solid and porous 3D matrices, including composites with hydroxyapatite and collagen. The properties of scaffold surface are important for cell attachment and proliferation. To enhance cell adhesion to the surface, improve the gasdynamic properties, and increase permeability for substrates and cell metabolites, the scaffolds can be treated by physical factors or chemical reagents. Biocompatibility of PHA scaffolds has been enhanced by immobilizing collagen film matrices on the scaffold surface and coating with chitosan and chitosan/polysaccharides.

Membranes based on resorbable PHAs of different compositions have been constructed and characterized. Four PHA types have been studied: a homopolymer of 3-hydroxybutyric acid, copolymers of 3-hydroxybutyric and 4-hydroxybutyric acids, 3-hydroxybutyric and 3-hydroxyvaleric acids, 3-hydroxybutyric and 3-hydroxyhexanoic acids. The microstructure of the surface of the membranes was analyzed using scanning electron microscopy and atomic force microscopy, showing that membranes prepared from $\mathrm{P}(3 \mathrm{HB}-c o-3 \mathrm{HHx})$ had the roughest surface and those prepared from $\mathrm{P}(3 \mathrm{HB}-\mathrm{co}-3 \mathrm{HV})$ had the smoothest surface. Copolymer membranes 
had smaller water contact angles and higher hydrophilicity than membranes prepared from the high crystallinity P3HB. In this study mouse fibroblast NIH 3T3 cells were cultivated on PHA membranes, and results of using Romanovskytype stain, the fluorescent DAPI DNA stain, and MTT-test assay showed that membranes prepared from PHAs of different chemical compositions did not exhibit cytotoxicity to cells cultured on them and proved to be highly biocompatible. Cell attachment and proliferation on PHA membranes were similar to those on polystyrene and better than those on membranes prepared from polylactic acid. The investigation of DNA synthesis in cells cultured on polymer matrices revealed no inhibition of ${ }^{3} \mathrm{H}$-thymidine incorporation by the nuclei of any of the cell types (fibroblasts, hepatocytes, and endothelial cells), compared with the control. Hence, direct contact of cells with the surface of PHA matrices of either composition did not result in the inhibition of DNA synthesis. The culturing of fibroblasts and hepatocytes on surfaces of those matrices for 3 days did not affect either cell generation time or protein synthesis. These results suggest that PHAs can be used as matrices for cell cultures.

Among promising approaches to preparing ultrafine fibers, membranes, and micro- and nano-particles as models of cell scaffolds are nanotechnological methods such as microencapsulation and electrostatic spinning (ESS). The principle of the ESS process is as follows: filaments are formed in a strong electric field between two oppositely charged electrodes, with one electrode placed into polymer solution or melt and the other placed on the metal collector (matrix). Depending on the applied voltage, polymer molecular mass, the density of the solution, and the distance between the solution and the collector, the resulting fibers may be of different diameters and structures. The ESS can be used to prepare ultrafine fibers and porous structures based on them from solutions and melts of variously structured polymers. The development of novel biomedical technologies of cellular and tissue engineering has attracted the attention of researchers to this method. We used the ESS technique to prepare ultrafine $\mathrm{P}$ (3HB-co3HV) fibers.

Micro- and nano-size particles were prepared by microencapsulation techniques, which have been actively developed in recent years. They are used as controlled drug delivery systems and cell culture scaffolds. These particles have very large surface areas and can be implanted subcutaneously, intramuscularly, and by infusion that makes them very promising forms. Experimentally prepared variously-sized PHA microparticles proved to be of good quality. It was found that the yield of microspheres, their structure and sizes were affected by the fabrication conditions: the type of emulsion, the technique of dispersion, and the temperature of the medium. Microspheres of consistently good quality were prepared from PHA using the method of solvent evaporation from double and triple emulsions. Biocompatibility of the microparticles was proved in cell cultures and in experiments with animals that received them via injection.

Using mechanical-physical method, we prepared solid and porous 3D matrices from $\mathrm{P} 3 \mathrm{HB}$ and $\mathrm{P} 3 \mathrm{HB} /$ hydroxyapatite composites and studied their structure and physicochemical properties. Hybrid matrices were seeded with osteoblastic cells. Biocompatibility and functional properties of the matrices were confirmed in vitro, using MTT-test assay and evaluation of the activity of alkaline phosphatase (which indicates osteoblast differentiation), and in vivo, in ectopic bone formation assay (Shishatskaya et al., 2006). The results of the study suggested that $\mathrm{P} 3 \mathrm{HB} /$ hydroxyapatite hybrid 3D matrices have a good osteogenic potential, facilitate bone formation from mesenchymal stem cells, and can be used 
in further studies as bioactive constructs for bone defect repair.

PHAs were studied as matrices for holding and delivering drugs or in controlled drug delivery systems. Prepared polymer films, tablets, and microparticles were loaded with hemoglobin, shikonin, antibiotics, and antiproliferative drugs; the studies addressed liquation kinetics of the preparations in biological media and degradation dynamics of the polymeric matrix. The most promising drug delivery systems seem to be polymer microparticles of diameters $0.5 \mu \mathrm{m}$ to $5.0 \mu \mathrm{m}$, which can function in vivo for up to 12 weeks; they can be injected intramuscularly, intraperitoneally, and intravenously (Shishatskaya et al., 2008). An experimental prolonged-action system in the form of microparticles was constructed for rubomycin hydrochloride - a cytostatic drug. Experiments on laboratory animals intraperitoneally injected with microspheres showed that initial drug concentration in the blood and peritoneal fluid could be maintained for 10 days. The efficacy of PHA microparticles loaded with rubomycin was demonstrated in experiments with laboratory mice inoculated with a $100 \%$ lethal dose of Ehrlich ascites carcinoma (EAC) cells $\left(3 \times 10^{6} \%\right.$ mouse). It was found that the experimental form of rubomycin hydrochloride encapsulated into PHA microspheres and intraperitoneally injected to laboratory mice significantly inhibited proliferation activity of EAC cells and enhanced the survival of tumor-bearing mice to $40 \%$ (Shishatskaya et al., 2008).

Hybrid composites consisting of different ratios of $\mathrm{P} 3 \mathrm{HB}$ (the best known type of PHA family) and biological hydroxyapatite were prepared as materials for reparative osteogenesis; their structure and properties were thoroughly examined. They were used to fabricate a series of 3D implants (Shishatskaya et al, 2006). The tested constructs were found to be biocompatible; they neither caused any adverse effect on the state of the animals, their immunity, and blood picture nor triggered any negative tissue response at the site of implantation. Ectopic bone formation assay and experiment with the model of segmental osteotomy showed that polyhydroxybutyrate alone and $\mathrm{P} 3 \mathrm{HB} /$ hydroxyapatite composites have pronounced osteoplastic properties, slowly degrade in vivo, and facilitate bone tissue formation (Shishatskaya, 2006). Thus, PHAs can be proposed as osteoplastic materials for bone tissue repair.

The described studies provided new data on the promising biomaterial and its potential for the development of medical technologies (surgical reconstruction, orthopedic and trauma surgery, cardiovascular and abdominal surgery) and pharmacology.

The study was supported by the project initiated by the Government of the Russian Federation (Decree No. 220 of 09.04.2010) for governmental support of scientific research conducted under the guidance of leading scientists at Russian Institutions of Higher Education (Agreement No. 11.G34.31.0013).

\section{References}

Amass W., Amass A., Tighe B.A. (1998) Review of biodegradale polymers: uses, current developments in the synthesis and characterization of biodegradable polyesters, blends of biodegradable polymers and recent advances in biodegradation studies. Polymer Int. 47: 89-144.

Choi J., Lee S.Y. (1999) Factors affecting the economics of polyhydroxyalkanoate production by bacterial fermentation. Appl. Microbiol. Biotechnol. 51: 13-21. 
Cromwick A.-M., Foglia T., Lenz R.V. (1996) The microbial production of poly(hydroxyalkanoates) from tallow. Appl. Microbiol. Biotechnol. 46: 464-469.

Doi Y., Segawa A., Kunioka M.(1990) Biosynthesis and characterization of poly(3-hydroxybutyrateco-4-hydroxybutyrate) in Alcaligenes eutrophus. Int. J. Biol. Macromol. 12: 106-111.

Durner R., Witholt B., Egli T. (2000) Accumulation of poly[(R)-3-hydroxyalkanoates] in Pseudomonas oleovorans during growth with octanoate in continuous culture at different dilution rates. Appl. Environ. Microbiol. 66: 3408-3422.

Fakoussa R.M., Hofrichter M. (1999) Biotechnology and microbiology on coal degradation. Appl. Microbiol. Biotechnol. 52: 25-40.

Füchtenbuch B., Steinbüchel A. (1999) Biosynthesis of polyhydroxyalkanoates from low-rank coal liquefaction products by Pseudomonas oleovorans and Rhodococcus rubber. Appl. Microbiol. Biotechnol. 52: 91-95.

Hasenberg W., Witholt B. (1997) Efficient production of medium-chain-lenghth poly(3hydroxyalkanoates) from octane by Pseudomonas oleovorans: economic considerations. Appl. Microbiol. Biotechnol. 48: 588-596.

Ishizaki A., Tanaka K., Taga N. (2001) Microbial production of poly-D-3-hydroxybutyrate from $\mathrm{CO}_{2}$. Appl. Microbiol. Biotechnol. 57: 6-12.

Kimura H., Iwama M., Sasaki S., Takeishi M. (1999) Production of polyester blend of poly(3hydroxybutyrate-co-4-hydroxybutyrate) and poly(3-hydroxyalkanoate) with saturated and unsaturated monomers from 4-hydroxybutyric acid by Chromobacterim sp. Chem. Lett. 28: 737-738.

Kimura H., Ohura T., Matsumoto T., Ikarashi T. (2008) Effective biosynthesis of poly(3hydroxybutyrate-co-4-hydroxybutyrate) with high 4-hydroxybutyrate fractions by Wautersia eutropha in the presence of $\alpha$-amino acids. Polym. Int. 57: 149-157.

Kunioka M., Kawaguchi Y., Doi Y. (1989) Production of biodegradable copolyesters of 3-hydroxybutyrate and 4-hydroxybutyrate by Alcaligenes eutrophus. Appl. Microbiol. Biotechnol. 30: 569-573.

Lee S.Y. (1998) Poly(3-hydroxyalkanoate) production from xylose by recombinant E. coli. Bioprocess. Engin. 18: 397-399.

Lee I.Y., Kim C.H., Yeon B.K., Hong W.K., Vhoi E.S., Rhee S.K., Park Y.H., Sung D.H., Baek W.H. (1997) High production of D- $\beta$-hydroxybutyric acid from methacrilic acid by Candida rugosa and its mutant. Bioprocess Engin. 16: 247-252.

Lee Y.-H., Kang M.-S., Jung Y.-M. (2000) Regulating the molar fraction of 4-hydroxybutyrate in poly(3-hydroxybutyrate-4-hydroxybutyrate) biosynthesis by Ralstonia eutropha using propionate as a stimulator. J. Biosci. Bioeng. 89: 380-383.

Mitomo H., Hsieh W.-C., Nishiwaki K., Kasuya K., Doi Y. (2001) Poly(3-hydroxybutyrate-co-4hydroxybutyrate) produced by Comamonas acidovorans. Polymer 42: 3455-3461.

Nakamura S., Doi Y., Scandola M. (1992) Microbial synthesis and characterization of poly(3hydroxybutyrate-co-4-hydroxybutyrate). Macromolecules 25: 4237-4241.

Proizvodstvo belka na vodorode (Protein production from hydrogen) (1980) Ed. I.I. Gitelson. Novosibirsk: Nauka, 150 p. (in Russian).

Rao U., Sridhar R., Sehgal P.K. (2010) Biosynthesis and biocompatibility of poly(3-hydroxybutyrateco-4-hydroxybutyrate) produced by Cupriavidus necator from spent palm oil. Biochem. Eng. J. 49: 13-20. 
Saito Y., Doi Y. (1994) Microbial synthesis and properties of poly(3-hydroxybutyrate-co-4hydroxybutyrate) in Comamonas acidovorans. Int. J. Biol. Macromol. 16: 99-104.

Savelieva N.D. (1979) Behavior of hydrogen bacteria towards carbon monoxide. Mikrobiologiya (Microbiology) 48: 360-362 (in Russian).

Sevastianov V.I., Shishatskaya E.I., Perova N.V., Volova T.G., Kalacheva G.S. (2003) Production of purified polyhydroxyalkanoates (PHAs) for applications in contact with blood. J. Biomaterial Science 14: 1029-1042.

Shishatskaya E.I., Eremeev A.V., Gitelson I.I. (2001) A study of the properties of biodegradable polymers in animal cell culture. Perspectivnyye materialy (Promising materials) 3: 40-47 (in Russian).

Shishatskaya E.I., Volova T.G., Gitelson I.I. (2002a) In vivo toxicological evaluation of polyhydroxyalkanoates. Doklady RAN (Proceedings of the Russian Academy of Sciences) 383: 565-567.

Shishatskaya E.I., Volova T.G., Efremov S.N., Puzyr A.P., Mogilnaya O.A., Gitelson I.I. (2002b) Tissue response to the implantation of biodegradable sutures based on polyhydroxybutyrate. Doklady RAN (Proceedings of Russian Academy of Sciences) 383: 838-842 (in Russian).

Shishatskaya E.I., Volova T.G., Efremov S.N., Puzyr A.P., Mogilnaya O.A. (2004) Tissue response to the implantation of biodegradable polyhydroxyalkanoate sutures. J. Mater. Sci.: Mater. Med. 15: 719-728.

Shishatskaya E.I., Volova T.G., Zhemchugova A.V. (2005) A study of biodegradable polyhydroxyalkanoates as anti-tumor drug carrier. Antibiotiki i chimioterapiya (Antibiotics and Pharmacotherapy). 2 - 3: 3-14 (in Russian).

Shishatskaya E.I., Chlusov I.A., Volova T.G. (2006) A hybrid PHA-hydroxyapatite composite for biomedical application: production and investigation. J. Biomater. Sci. Polymer Ed. 17: 481-498.

Shishatskaya E.I., Voinova O.N., Goreva A.V., Mogilnaya O.A., Volova T.G.(2008)Biocompatability of polyhydroxybutyrate microspheres: in vitro and in vivo evaluation. J. Mater. Sci.: Mater. Med. 19: 2493-2502.

Shishatskaya E.I., Goreva A.V., Kalacheva G.S., Volova T.G. (2011) Biocompatability and resorption of intravenously administered polymer microparticles in tissue of internal organs of laboratory animals. J. Biomater. Sci. Polym. Ed. 22: 2185-2203.

Stasishina G.N., Volova T.G. (1996) Shtamm bakterii Alcaligenes eutrophus - produtsent belkovoi biomassy (The strain of the bacterium Alcaligenes eutrophus - a producer of protein biomass). Patent BI. № - (in Russian).

Steinbüchel A., Valentin H.E. (1995) Diversity of bacterial polyhydroxyalkanoic acids. FEMS Microbiol. Lett. 128: 219-228.

Sudesh K., Abe H., Doi Y. (2000) Synthesis, structure and properties of polyhydroxyalkanoates: biological polyesters. Prog. Polym. Sci. 25: 1503-1555.

Sugimoto T., Tsuge T., Tanaka K., Ishizaki A. (1999) Control of acetic acid concentration by pHstat continuous substrate feeding in heterotrophic culture phase of two-stage cultivation of Alcaligenes eutrophus for production of $\mathrm{P}(3 \mathrm{HB})$ from $\mathrm{CO}_{2}, \mathrm{H}_{2}$, and $\mathrm{O}_{2}$ under non-explosive conditions. Biotechnol. Bioengin. 62: 625-631.

Tanaka K., Ishizaki A., Kanamaru T., Kawano T. (1994) Production of poly(D-3-hydroxybutyrate) from $\mathrm{CO}_{2}, \mathrm{H}_{2}$ and $\mathrm{O}_{2}$ by high cell density autotrophic cultivation of Alcaligenes eutrophus. Biotechnol. Bioeng. 45: 268-275. 
Tsuge T. (2002) Metabolic improvements and use of inexpensive carbon sources in microbial production of polyhydroxyalkanoates. J. Biosci. Bioeng. 94: 579-584.

Volova T.G., Kalacheva G.S. (2005) The synthesis of hydroxybutyrate and hydroxyvalerate copolymers by the bacterium Ralstonia eutropha. Microbiology 74: 54-59.

Volova T.G., Voinov N.A. (2003) Biosynthesis of biodegradable polymers polyhydroxyalkanoates (PHAs) on hydrogen of different origin: kinetic aspects. In: Zaikov G.E., Jimenez A. (eds.) Quantitative level of chemical reactions. New York: Nova Science Publ., p. 173-184.

Volova T.G., Voinov N.A. (2004) Kinetic and production parameters of the culture of Ralstonia eutropha accumulating polyhydroxyalkanoates on coal processing products. Prikladnaya biokhimiya i mikrobiologiya (Applied biochemistry and microbiology) 40: 249-252 (in Russian).

Volova T.G., Kalacheva G.S., Fyodorova Y.V. (1990) Regulation of synthesis of microbial polyhydroxybutyrate by parameters of the culture medium. In: Mikrobnaya biokonversiya (Microbial bioconversion). Riga, p. 119-129 (in Russian).

Volova T.G., Kalacheva G.S., Konstantinova V.M., Puzyr A.P. (1992a) The effect of growth conditions on polyhydroxybutyrate accumulation by hydrogen bacteria. Prikladnaya biokhimiya i mikrobiologiya (Applied biochemistry and microbiology) 28: 221-222 (in Russian).

Volova T.G., Lukovenko S.G., Vasiliev A.D. (1992b) Production and investigation of physicochemical properties of microbial polyhydroxyalkanoates. Biotekhnologiya (Biotechnology) 1: 19-22 (in Russian).

Volova T.G., Konstantinova V.M., Guseinov O.A. (1992c) Synthesis of thermoplastic degradable polyhydroxyalkanoates by chemolithotrophic bacteria. Biotekhnologiya (Biotechnology) 5: 81-83 (in Russian).

Volova T.G., Guseinov O.A., Kalacheva G.S., Medvedeva S.E., Pusir A.P. (1993) Effect of carbon monoxide on metabolism and ultrastructure of carboxydobacteria. World Appl. Microbiol. Biotechnol. 9: $160-163$.

Volova T.G., Kalacheva G.S., Konstantinova V.M. (1994) Polyhydroxybutyrate accumulation by the aerobic CO-oxidizing carboxydobacterium Seliberia. Mikrobiologiya (Microbiology) 63: 211-216 (in Russian).

Volova T.G., Belyaeva O.G., Kalacheva G.S., Plotnikov V.F. (1996a) Production and investigation of microbial heteropolymer polyhydroxyalkanoates. Doklady RAN (Proceedings of Russian Academy of Sciences) 346: 558-561 (in Russian).

Volova T.G., Kalacheva G.S., Konstantinova V.M. (1996b) Sposob polucheniya geteropolimera $\beta$-oksimaslyanoi i $\beta$-oksivalerianovoi kislot (The method of receiving of $\beta$-hydroxybutyrate and $\beta$-hydroxyvalerate copolymers). Patent BI. № 2051968 (in Russian).

Volova T.G., Kalacheva G.S., Altukhova O.V.(2001)Autotrophic synthesis of polyhydroxyalkanoates by the bacterium Alcaligenes eutrophus in the presence of carbon monoxide. Mikrobiologiya (Microbiology) 70: 745-752 (in Russian).

Volova T.G., Kalacheva G.S., Altukhova O.V. (2002) Autotorophic synthesis of PHAs by Ralstonia eutropha in the presence of carbon monoxide. Appl. Microbiol. Biotechnol. 58: 675-678.

Volova T.G., Sevastianov V.I., Shishatskaya E.I. (2003a) Polioxialkanoaty - biorazrushaemyye polimery dlya meditsiny (Polyhydroxyalkanoates - biodegradable polymers for medicine). Novosibirsk: SB RAS Publishers, 330 p. (in Russian). 
Volova T.G., Shishatskaya E.I., Nekrasov Yu.P., Gordeev S.A. (2003b) Production and investigation of polyhydroxyalkanoate films and sutures. Plasticheskiye massy (Plastics) № 3: 6-8 (in Russian).

Volova T.G., Shishatskaya E.I., Sevastianov V.I., Efremov S.N., Mogilnaya O.A. (2003c) Results of biomedical investigations of PHB and PHB/PHV fibers. Biochemical Engin. J. 16: 125-133.

Volova T.G., Voinov N.A., Muratov V.S., Bubnov N.V., Gurulev K.V., Kalacheva G.S., Gorbunova N.V., Plotnikov V.F., Zhila N.O., Shishatskaya E.I., Belyaeva O.G. (2006a) Pilot production of biodegradable biopolymers. Biotekhnologiya (Biotechnology) 6: 28-34 (in Russian).

Volova T.G., Sevastianov V.I., Shishatskaya E.I. (2006b) Polioxialkanoaty - biorazrushaemyye polimery dlya meditsiny (Polyhydroxyalkanoates - biodegradable polymers for medicine). Krasnoyarsk: Platina, 287 p. (in Russian).

Volova T.G., Kalacheva G.S., Steinbüchel A. (2008) Biosynthesis of multi-component polyhydroxyalkanoates by the bacterium Wautersia eutropha. Macromol. Symp. 269: 1-7.

Xie W.P., Chen G.-Q. (2008) Production and characterization of terpolyester poly(3hydroxybutyrate-co-4-hydroxybutyrate-co-3-hydroxyhexanoate) by recombinant Aeromonas hydrophila 4AK4 harboring genes phaPCJ. Biochem. Eng. J. 38: 384-389.

\section{Фундаментальные основы производства}

\section{и применения биодеградируемых}

\section{полигидроксиалканоатов}

Т.Г. Волова ${ }^{\mathrm{a}, \tilde{\sigma}}$, Е.И. Шишацкая ${ }^{\mathrm{a}, \boldsymbol{\sigma}}$, Н.О. Жила ${ }^{\mathrm{a}, \tilde{0}}$, Е.Г. Киселев ${ }^{\mathrm{a}, \boldsymbol{\sigma}}$, П.В. Миронов ${ }^{\mathrm{g}}$, А.Д. Васильев ${ }^{\mathrm{r}}$ И.В. Петерсон ${ }^{\text {, }, ~ Э . Д . ~ С и н с к и ~}{ }^{\tilde{0}, \mathrm{e}}$

${ }^{a}$ Институт биофизики СО РАН,

Россия 660036, Красноярск, Академгородок

${ }^{\sigma}$ Сибирский федеральный университет, Россия 660041, Красноярск, пр. Свободный, 79 ${ }^{8}$ Сибирский государственный технологический университет,

Россия 660049, Красноярск, пр. Мира, 82

${ }^{2}$ Институт физики им. Л.В. Киренского СО РАН,

Россия 660036, Красноярск, Академгородок

${ }^{\circ}$ Институт химии и химической технологии СО РАН,

Россия 660036, Красноярск, Академгородок

' Массачусетский технологический институт,

США 02139, Массачусетс, Кембридж

Полигидроксиалканоаты (ПГА) - перспективные материалы, которые могут заменить пластмассы на углеводородной основе, и они исследуются уже в течение длительного времени. Данная работа рассматривает воздействие различных условий углеродного питания на синтез полигидроксиалканоатов бактериями Ralstonia eutropha. Прежде всего ПГА являются запасными веществами для многих организмов. Многие аспекты физиологии 
накопления и разрушения ПГА остаются пока не изученными. Измерение активности ключевых ферментов ЗПГБ на протяжении роста клетки показывает связь максимумов активности ацетоацетил-КоА редуктазы и синтазы с биосинтезом ЗПГБ. Были исследованы кинетические параметры роста и накопления полигидроксиалканоатов и параметры газообмена культуры итамма водородных бактерий Ralstonia eutropha B 5786, yстойчивого к СО, при культивировании на синтез-газе - продукте газификации бурых углей. Проведено сравнение полученных результатов с данныли, полученными при вырашивании бактерий на электролитическом водороде, и показано, что синтез-газ может успешно применяться для получения ПГА. В экспериментах с природным штаммом бактерий впервые было показано, что при миксотрофных условиях роста $-\mathrm{CO}_{2}+$ дополнительный субстрат (алкановые кислоты) - бактерии способны синтезировать многокомпонентные ПГА, состоящие из коротко- и среднецепочечных мономеров с длиной ичепи от 4 до 8 атомов углерода. Показано, что состав ПГА зависит от типа дополнительного субстрата. Жирные кислоты с нечётным количеством атомов углерода стимулируют бактерии синтезировать многокомпонентные ПГА, состоящче из таких основных компонентов, как 3-гидроксибутират, 3-гидроксивалерат и 3-гидроксигексаноат, и второстепенных, эпизодических компонентов: 3-гидроксигептаноата и 3-гидроксиоктаноата. Жирные кислоты с чётныл количеством атомов углерода стимулируют синтез как соответствующих им мономеров (3-гидроксигексаноата и 3-гидроксиоктаноата), так и 3-гидроксивалерата, что позволяет получать четырёхкомпонентные ПГА, содержашие 3-гидроксибутират и 3-гидроксигексаноат в качестве основных компонентов. Было синтезировано семейство коротко- и среднецепочечных четырёх- и пятикомпонентных ПГА и проведено исследование их физико-химических и медико-биологических свойств.

Ключевые слова: биополимеры, полигидроксиалканоаты, субстраты, синтез, свойства, обработка, медико-биологическое применение 